Volume 10 Issue 1 (2021) Pages 121-142

Ta'dib: Jurnal Pendidikan Islam

ISSN: 2528-5092 (Online) 1411-8173 (Print)

https://ejournal.unisba.ac.id/index.php/tadib/article/view/8232

\title{
CURRICULUM DEVELOPMENT STRATEGIC MANAGEMENT MODEL ISLAMIC INTERNATIONAL BOARDING SCHOOL (IIBS) IN THURSINA IIBS MALANG
}

\author{
Dwi Fitri Wiyono \\ Pendidikan Islam, Fakultas Agama Islam, Universitas Islam Malang \\ Email: dwi.fitri@unisma.ac.id \\ DOI: https://doi.org/10.29313/tjpi.v10i1.8232 \\ Received: July 21th, 2020. Accepted: July 28th, 2021. Published: July 28th, 2021.
}

\begin{abstract}
The aims of this study to find the process of formulating, implementation and evaluation of the curriculum strategy strategy for the International Islamic Boarding School Islamic education model at the Thursina IIBS Islamic Education Institute Malang Regency. The method in this study uses a qualitative approach, case study research with multi-site design, data collection techniques, namely: interviews, observations, and document studies, analysis techniques using single cases and cross-cases. The results of this study are: (1) Formulation of the curriculum development strategy of the International Islamic Boarding School model through the following stages: first, the input strategy: combining the Islamic boarding school curriculum, the national curriculum and the international curriculum namely the Coumbridge Curriculum, graduates from the International Islamic Boarding School (IIBS) will have a charter Coumbbrige, Second, process strategy: developing curriculum through language strengthening and selfdevelopment with global insight (enrichment and extension), third, output strategy: commitment to the quality of graduates who have an Islamic personality (morally excelent), globally minded (internationally minded), and spirited leader (an inspiring leader). (2) Implementation of the strategy of developing Islamic education curriculum model International Islamic Boarding School (IIBS), implementation of the curriculum through the process of organizational culture and refocusing the organization and specialization class (Moslem scholar, entrepreneur, sciencepreneur, professional) (3) Evaluation of strategy development of Islamic education curriculum the International Islamic Boarding School model, the evaluation adapts to the standard curriculum blending the pesantren curriculum, national, and international, the evaluation is carried out holistically starting from the input, process, output, and outcome by involving all stakeholders in curriculum development.
\end{abstract}

Keywords: Management Strategic; Curriculum; Islamic International Boarding School.

\begin{abstract}
Abstrak
Penelitian ini bertujuan untuk menemukan proses formulasi, implementasi dan evaluasi terbadap strategi kurikulum pendidikan Islam model International Islamic Boarding School di Lembaga Pendidikan Islam Thursina IIBS Kabupaten Malang. Metode dalam penelitian ini menggunakan pendekatan kualitatif jenis penelitian studi kasus dengan rancangan multi situs, teknik, pengumpulan data yaitu: wawancara, observasi, dan studi dokumen, teknik analisis menggunakan kasus tunggal dan lintas kasus. Hasil penelitian ini adalab: (1) Formulasi strategi pengembangan kurikulum model International Islamic Boarding School melalui tahapan: pertama, Strategi input: memadukan kurikulum kepesantrenan, kurikulum nasional serta kurikulum internasional yaitu Kurikulum Coumbrige, lulusan dari International Islamic Boarding School (IIBS) akan memiliki piagam Coumbrige, Kedua, Strategi proses: mengembangkan kurikulum melalui penguatan bahasa (languages) dan pengembangan diri yang berwawasan global (enrichment and extension), ketiga, strategi output: komitmen pada kualitas lulusan yang berkepribadian Islami (morally eccelent), berwawasan global (internationally
\end{abstract}


minded), dan beriina pemimpin (an inspiring leader). (2) Implementasi strategi pengembangan kurikulum pendidikan Islam model International Islamic Boarding School (IIBS), implementasi kurikulum melalui proses organizational culture and refocusing the organization dan specialization class (Moslem scholer, entrepreneur, sciencepreneur, professional) (3) Evaluasi strategi pengembangan kurikulum pendidikan Islam model International Islamic Boarding School, evaluasi menyesuaikan dengan standart kurikulum perpaduan antara kurikulum pesantren, nasional, dan internasional, evaluasi dilakukan secara menyelurub (bolistic) mulai dari input, proses, output, dan outcome dengan melibatkan seluruh stakeholder dalam pengembangan kurikulum.

Kata Kunci: Manajemen Strategik; Kurikulum; Islamic International Boarding School.

\section{PENDAHULUAN}

Era revolusi industri 4.0 meniscayakan perubahan kondisi global yang berdampak pada tatanan kelembagaan dan kurikulum pendidikan, khususnya kurikulum pendidikan Islam dalam lembaga pondok pesantren. di Indonesia, lembaga pondok pesantren menjadi penanda perkembangan kurikulum pendidikan Islam yang menurut sebagian ilmuan pendidikan Islam memiliki corak tradisional sebagai petanda akulturasi pendidikan Islam dan budaya nusantara. Untuk menjawab perubahan dan situasi global, arah baru manajemen pondok pesantren khususnya kurikulum pendidikan Islam, penting untuk dikaji ulang terutama berkaitan dengan relevansi dengan kebutuhan masyarakat.

Kondisi diatas mendorong adanya transformasi Lembaga Pendidikan Islam khususnya pondok pesantren mengembangkan kurikulum agar sesuai dengan tuntutan zaman yang masuk perluasan globalisasi. Lembaga Pendidikan Islam yang modern dan bercorak global dikembangkan oleh Thursina International Islamic Boarding School (IIBS) Malang, yang kemudian peneliti sebut LPI Thursina IIBS
Malang. Lembaga Pendidikan Islam ini berbasis budaya kehidupan pondok pesantren yang diistilahkan secara global adalah International Islamic Boarding School (IIBS). Pondok pesantren ini memiliki jenjang program sekolah dasar menengah yaitu: jenjang Sekolah Menengah Pertama (SMP) dan Sekolah Menengah Atas (SMA). Secara geografis pondok pesantren ini berada dilingkungan bukit dan pegunungan yang asri dan sejuk dilengkapi dengan infrastruktur megah dan modern. Secara administrative Lembaga pendidikan ini terletak di Kabupaten Malang, di jalan Sentono Nomor. 15A, di Landungsari, Kabupaten Malang Jawa Timur (Thursina IIBS, n.d.-a)(Observasi, 21 Februari 2021).

LPI Thursina IIBS Malang dalam proses pengembangan kurikulum, secara khusus mengembangkan minat santri atau peserta didik dalam kemampuan akademik. Peserta didik diberikan kebebasan dalam memilih program secara spesifik sesuai kemampuan dan kompetensi akademik secara terukur berdasarkan peminatan program, antara lain adalah program tahfidz al-Qur'an, olimpiade sains dan matematika, penulisan 
dan desain pemrograman (Thursina IIBS, 2021).

Pengembangan kurikulum integrative dan holistik yang didesain menggunakan manajemen yang efektif dan meiliki tanggungjawab dengan model strategi modern dan salaf berdasarkasn al-Qur'an, kurikulum nasional dan internasional. Dalam rangka mendukung pengembangan kurikulum Lembaga Pendidikan Islam Thursina IIBS kemudian melakukan kemitraan dan kerjasama dengan lembagalembaga Internasional, diantaranya adalah: Singapore, ADNI International Islamic School, Malaysia, S. R. Agama Ustman bin Affan, Malaysia, Phatnawitya Demonstration School, Thailand, Santi Witya School, Thailand, Pathanasard School. Madrasah Alive dan Al-Irsyad Al-Islamy (Dokumentasi, 2021).

Karakteristik dari pengembangan kurikulum yang unik di LPI Thursina IIBS Malang ini adalah program Best Tourism Object at Batu City and Malang (PBL), kurikulum program ini merupakan model pengembangan kurikulum pembelajaran yang memiliki basis kurikulum pembelajaran proyek yang bertujuan untuk mengembangkan pembelajaran secara bolistic sebagaimana prinsip-prinsip kurikulum yang menjadi dasar pengembangan kurikulum di LPI Thursina IIBS Malang, program ini merupakan proses pendidikan yang memfasilitasi peserta didik untuk dapat berpikir interdisipliner dalam mengatasi problem yang berkembang di masyarakat. Project Base Learning (PBL) adalah sebuah proses pembelajaran yang menggunakan proyek terintegrasi dengan berbagai mata pelajaran di sekolah. Dalam proses belajar PBL peserta didik diberikan masalah (problem based) dan melalui suatu proyek akademik, peserta didik mampu memecahkan masalah secara logis sesuai kebutuhan masyarakat.

Metode pembelaran menggunakan Manbaji yang dalam bahasa arab menjadi kompetensi dasar dan utama dalam mempelajari dan memahami Al-Quran serta ilmu-ilmu Islam. Tapi demikian, bagi sebagian orang belajar bahasa Arab masih sulit (Observasi, 21 Februari 2021). Oleh karena itu, keberadaan metode yang efektif dan efisien menjadi kunci untuk mengatasi masalah dan metode manhaji hadir sebagai solusinya. Manhaji adalah metode belajar bahasa Arab, terutama nabwu dan shorof material yang praktis, aplikatif, inovatif, mudah, dan menyenangkan. Kedua bahan tersebut dirumuskan dan digabungkan menjadi satu sehingga memudahkan para pemula yang tidak tahu keinginan bahasa Arab untuk menguasai bahasa Al- Qur'an dan buku-buku (turat). Metode Al-Muyassar terdiri dari 3 tahap utama dari murajaatul qarib, bifdzul jadid, dan at-tahdhir. Berikutnya adalah metode ini berfokus pada: Keterlibatan guru dan partisipasi peserta didik aktif efektif (Dokumentasi, 2021). Adanya kerja sama dan dinamika kelompok. Integrasi mendengarkan (audio) dan membaca (visual) peserta didik. 
Capaian kompetensi lulusan di SMA

LPI Thursina IIBS Malang, antara lain adalah: pertama, Memiliki kepribadian Islami (morally excellent) yang ditandai dengan karakteristik profil lulusan dengan sikap kepribadian Islami; Kedua, Memiliki wawasan global (internationally minded); Ketiga, Memiliki jiwa pemimpin (an inspiring leader) dan memiliki kemampuan menghafal, menterjemah, dan memahami al-Qur'an secara temati 5-10 juz (tafsir maudhu'i). Berikutnya adalah peserta didik mampu menghafal dan menterjemahkan minimal 50-200 hadist, mampu berkompetisi dan berprestasi di tingkat nasional maupun internasional (Observasi, 21 Februari 2021)

Selain kempuan memahami sumber hokum Islam secara tematik, peserta didik di SMA LPI Thursina IIBS Malang, memiliki kemampuan untuk menjadi role model dalam komunikasi bahasa asing (Bahasa Arab dan Bahasa Inggris), menjadi role model dalam melaksanakan tugas dan tanggung jawab pribadi secara mandiri, memiliki kemampuan berorganisasi dan mengkoordinasikan tugas kelompok secara efektif, kemampuan menjadi problem solver diri sendiri, keluarga dan orang lain serta memiliki kemampuan menghasilkan minimal satu produk atau karya tulis ilmiah.

Kurikulum diatas menyesuaikan dengan situasi global dan memberikan tantangan bagi LPI Thursina IIBS Malang dalam menyiapkan pendidikan di level perguruan tinnggi dan di dunia kerja. LPI
Thursina IIBS Malang menegaskan konsep Holistic dan Personalized secara komprehensif. Secara praktis konsep Personalized berarti peserta didik diberikan program secara sepesifik sesuai kompetensinya sekaligus penjurusan (specialization program) yang bukan hanya berdasar pada minat mereka tetapi juga hasil bimbingan konseling karier profesional sesuai rencana pekerjaan yang menjadi focus pengembangan diri peserta didik. Jurusan yang ditawarkan juga berbeda dengan sekolah pada umumnya (Observasi, 21 Februari 2021).

Jurusan tersebut merupakan research yang telah dilakukan dengan melibatkan berbagai praktisi, mulai dari pembisnis, profesional, ulama, pemimpin perusahan dan organisasi, akademisi, dan calon wali santri. Dari program penjurusan itu diharapkan kemampuan santri yang berkaitan dengan mindset, skillset dan toolset akan diasah sejak dini sesuai dengan bidang yang diminati.

Berdasarkan konteks penelitian diatas, peneliti menyimpulkan tema penting untuk melakukan penelitian manajemen strategik pengembangan kurikulum LPI Thursina IIBS Malang yaitu terkait dengan proses manajemen strategik yaitu: formulasi strategi, implementasi strategi, evaluasi dan pengendalian strategi dalam pengembangan kurikulum di Lembaga Pendidikan Islam.

\section{METODE PENELITIAN}

Peneliti menggunakan pendekatan kualitatif berdasarkan konteks penelitian dan 
studi pendahuluan, peneliti memandang fenomena alamiah secara komprehensif pada lokus penelitian pada konteks manajemen strategik kurikulum pendidikan Islam model International Islamic Boarding School di LPI Thursina IIBS Malang. Jenis penelitian menggunakan studi kasus, alasan yang melatarbelakangi adalah studi kasus memiliki persamaan dengan kajian etnografi dan etnometodologi, sedangkan konteks perbedannnya terletak pada ruang lingkup kajian alamiahnya. Etnometodologi dan etnografi mengungkap solusi berdasarkan suatu permasalahan, sedangkan studi kasus fokus pada kajian mendalam tentang keunikan atau ciri khas suatu program maupun peristiwa dengan mengumpulkan informasi serta mengikuti prosedur tanpa adanya waktu yang ditentukan.

Adapun teknik pengumpulan data yaitu: wawancara, observasi, dan studi dokumen, teknik analisis menggunakan kasus tunggal. Peneliti berinteraksi dengan subyek penelitian melalui wawancara mendalam dan observasi pada latar dimana fenomena tentang proses formulasi strategi, implementasi, evaluasi dan pengendalian strategi pengembangan kurikulum pendidikan Islam model International Islamic Boarding School di LPI Thursina IIBS Malang yang menjadi fokus penelitian. Oleh karena itu, teknik wawancara dan observasi dalam penelitian kualitatif merupakan teknik yang digunakan. Disamping itu, bahan-bahan yang ditulis oleh atau tentang subyek digunakan untuk melengkapi data yang diperlukan. Prosedur yang terakhir adalah teknik dokumentasi.

Analisis data dilakukan dengan menelaah seluruh data yang telah terkumpul dari transkrip wawancara, catatan lapangan, dan bahan-bahan lain yang dikumpulkan untuk meningkatkan pemahaman tentang proses proses formulasi strategi, implementasi, evaluasi dan pengendalian strategi pengembangan kurikulum pendidikan Islam model International Islamic Boarding School di LPI Thursina IIBS Malang. Data yang berhasil dikumpulkan kemudian dianalisis menggunakan model analisis interaktif

Langkah selanjutnya peneliti melakukan uji keabsahan atau kesahihan data agar data yang diperoleh dapat dipertanggungjawabkan keshahihannya dan melakukan verifikasi data tersebut. Verifikasi adalah upaya pemeriksaan keabsahan data didasarkan atas kriteriakriteria tertentu untuk menjamin kepercayaan data yang diperoleh melalui penelitian. Uji keabsahan data dalam penelitian kualitatif meliputi antara lain; validitas internal, validitas eksternal, reliabilitas, dan obyektifitas. 


\section{HASIL PENELITIAN DAN PEMBAHASAN}

Hasil Penelitian

Karakteristik kurikulum di Lembaga Pendidikan Islam Thursina IIBS Malang adalah pengembangan kurikulum dilakukan melalui proses manajemen strategik berdasarkan visi, misi dan tujuan institusional untuk melahirkan generasi Muslim yang takwa, cerdas dan mandiri; memadukan kurikulum pendidikan nasional, kurikulum Cambridge International, kurikulum diniyah dan program pengembangan diri; pengembangan dan pelaksanaan kurikulum tidak hanya menekankan penguasaan isi kurikulum tetapi nilai-nilai keislaman dengan mengintegrasikan nilai-nilai tersebut dalam setiap aktifitas pembelajaran (Thursina IIBS, 2021)

Profil Manajemen Strategik. Model Kurikulum LPI Thursina IIBS Malang

LPI Thursina IIBS Malang merupakan lembaga pendidikan Islam berbasis boarding school yang mengembangkan Visi menjadi lembaga pendidikan berbasis pesantren yang unggul dan berstandar Internasional (Being a leading and world-class Islamic boarding school). LPI Thursina IIBS Malang adalah menyediakan lingkungan belajar yang religious, challenging dan rewarding yang berfokus pada pendidikan yang menyeluruh (bolistic) dan berimbang (balanced) sehingga melahirkan cendekiawan muslim yang berkepribadian Islami (morally excellent), berjiwa pemimpin (being an inspiring leader) dan berwawasan global (Dokumentasi, 2021).

LPI Thursina IIBS Malang memiliki rencana strategis pembangunan jangka panjang yang didesain melalui beberapa tahun tahapan antara lain adalah: tahun 2014-2017 menjadi Pondok Pesanren dengan Standart Nasional, tahun 2018-2020 menjadi Pondok pesantren terkemuka di dunia, tahun 20212025 menuju sekolah Islam yang berkelanjutan, tahun 2026-2030 menjadi pusat pendidikan Islam yang unggul, tahun 2031-2035 berkontribusi untuk kemajuan umat (Observasi, 27 Februari 2021)

Profil lulusan di LPI Thursina IIBS Malang antara lain adalah: pertama, memiliki kepribadian Islami (morally excellent) yang ditandai dengan karakteristik profil lulusan yang memiliki kepribadian Islami, yaitu: (a) memiliki aqidah Islam yang kokoh; (b) memiliki pemahaman Islam yang benar, luas dan mendalam; (c) lulus uji kompetensi standar internasional; (d) mampu menjadi role model dalam melaksanakan ibadah wajib dan sunnah; (e) memiliki syakhshiyah Islamiyah (kepribadian Islami) dan karakter nubuwah; (f) memiliki semangat juang keislaman yang tinggi. Kedua, berwawasan global (internationally minded) yang memiliki indikator, yaitu: (a) lulus uji kompetensi standar nasional; (b) kompetensi standar internasional; (c) kompetensi standar diniyah; (d) program pengembangan wawasan internasional (overseas program); (e) perguruan 
tinggi favorit pilihan di dalam dan luar negeri (Thursina IIBS, 2021).

Ketiga, Memiliki jiwa pemimpin (an inspiring leader), kemampuan menghafal dan memahami al-Qur'an secara tematik dan memiliki kemampuan menghafal dan menterjemahkan hadist, memiliki kemampuan berkompetisi sekaligus berprestasi di tingkat nasional dan internasional, memiliki kemampuan berkomunikasi dan berorganisasi, kemampuan komunikasi yang wajid adalah bahasa asing (bahasa arab dan bahasa Inggris), menjadi role model dalam melaksanakan tugas dan tanggung jawab pribadi secara mandiri, kemampuan menjadi problem solver diri sendiri, keluarga dan orang lain, berjiwa entrepreneur, menghasilkan minimal satu karya tulis/projek dan yang menjadi unggulkan adalah mampu menjadi da’i di keluarga dan masyarakat.

Formulasi strategi kurikulum pendidikan Islam model International Islamic Boarding School (IIBS) di Thursina IIBS Malang

Formulasi strategi kurikulum Pendidikan Islam didasarkan pada nilai-nilai filosofi dan prinsip kelembagaan yang gagas oleh para pendiri sebagaimana tertuang dalam aspirasi pendirian LPI Thursina IIBS Malang yaitu lembaga pendidikan Holistik (holistic) dan berimbang (Dokumentasi, 2021). Prinsip dasar pendidikan dan pengelolaan manajemen LPI Thursina IIBS Malang adalah berpegang pada prinsip pendidikan yang holistik, berimbang, relevan dan modern diharapan LPI Thursina IIBS Malang diharapkan mampu mengantarkan santri atau peserta didik menjadi generasi muslimmusimah abad modern yang berkrepibadian islami (morally excellent), berjiwa pemimpin (being an inspiring leader) dan berwawasan global (internationally-minded), sehingga mampu bersaing dan berdiri kokoh dalam mengemban amanah sebagai hamba dan khalifah Allah SWTT (Thursina IIBS, 2021).

Pendidikan bolistic adalah sebuah cara pandang dalam praktik sistem pendidikan multidimensional yang menjadi dasar dalam proses pengembangan kurikulum LPI Thursina IIBS Malang. Dasar dan prinsip ini sesuai dengan fitrah manusia yaitu: Allah SWT telah membekali manusia (peserta didik) dengan sifat dasar (fitrah) ketauhidan, kecerdasan intelektual dan kompetensi yang tinggi, emosi yang positif, integritas yang tinggi, perasaan yang halus serta fisik yang kuat dan sempurna. Semua potensi ini akan berkembang sesuai dengan pendidikan yang diberikan oleh kelembagaan pendidikan Islam.

Konsep pendidikan holistic (bolistic) didasarkan pada problem praktik pendidikan selama ini cenderung parsial dan terjadi dikotomik (pemisahan) antara kurikulum yang berbasis keilmuan yang dapat menghambat perkembangan kompetensi peserta didik. Konsep integrasi pendidikan Islam seperti contoh diatas hanya mampu mencetak generasi cerdas dan berdaya 
kreatifitas tinggi, tetapi belum didukung dari aspek secara vertical (spiritual) sehingga cenderung materialistik dan individualis. Disisi lain, system pendidikan di negaranegara muslim bersifat dogmatis dan konservatif sehingga mencetak generasi yang kurang berkompeten dan kurang memiliki kepercayaan diri sehingga belum memiliki kemampuan berkompetisi di berbagai sektor kehidupan.

Oleh karena itu, konsep pendidikan yang dikembangkan di LPI Thursina IIBS Malang berorientasi pada penyatuan dua paradigma dengan menjadikan konsep dalam ajaran Islam (al-Qur'an dan al-Hadits) sebagai basis utama dan pusat dari semua proses pendidikan yang ada. Dalam proses pendidikan, peserta didik akan mengikuti proses belajar (ta'lim) secara menyeluruh dan berimbang, proses pengkondisian dan pembentukan karakter atau adab (ta'dib) dan proses pensucian niat dan diri (tazkiyah) melalui program ibadah harian santri Wawancara, Eko, Principle Islamic Foundation Curriculum Thursina IIBS Malang, 2021)

Berikutnya adalah Proses dan tujuan pendidikan LPI Thursina IIBS Malang berorientasi secara seimbang balanced. Konsep keseimbangan (At-tawazun) merupakan sebuah prinsip dalam ajaran agama Islam. Prinsip keseimbangan memberikan aspek muatan kurikulum yang komprehensif yang secara proporsional sesuai dengan fitrah manusia yang memiliki tujuan dalam kebahagian di dunia dan akherat.

Oleh karena itu, konsep pendidikan yang dikembangkan LPI Thursina IIBS Malang mempertemukan kedua paradigma diatas sebagai sebuah konsep ajaran Islam (alQur'an dan al-Hadits) yang menjadi pondasi utama dan dasar dari proses pengembangan kurikulum. Dalam proses pengembangan kurikulum, peserta didik mengikuti aktifitas belajar (ta'lim) secara komprehensif dan proporsional, proses implementasi dan pembangunan karakter atau adab (ta'dib) dan proses pensucian niat dan diri (tarkiyah) melalui kegiatan ibadah harian santri (Observasi, 21 Februari 2021).

Prinsip dasar yang penting dalam pengembangan kurikulum yang perlu diperhatikan dan dipertimbangkan oleh para pengembang kurikulum sebelum mendesain kurikulum adalah komponen-komponen Pendidikan yaitu landasan agama, landasan filosofis, landasan sosial budaya, dan landasan psikologis. Aspek ini menjadi dasar yang menjadi landasan dalam mengembangkan kurikulum di LPI Thursina IIBS Malang. Pendidikan diusahakan harus mampu memberikan sentuhan (shibghah) yang baik melalui penyelenggaraan program agar dapat membentuk kematangan spiritual dan emosi, ketajaman fikir dan skills serta integritas yang terpuji. Tetapi, tidak semua lembaga pendidikan pondok pesantren mampu memberikan kebutuhan dasar row material tersebut sehingga berakibat pada lemahnya 
generasi muda yang ada masih belum mampu bersaing secara global.

Selain aspek filosofis, nilai-nilai yang menjadi dasar strategi dan komitmen kelembagaan LPI Thursina IIBS Malang dalam pegembangan kurikulum dari aspek kepesantrenan antara lain: (1) nilai-nilai religius, yaitu: kekuatan trilogy ajaran Islam (tauhid, Syariah, dan akhlak); (2) care, sikap kepedualian antar sesama; (3) open minded, memiliki wawasan yang luas dan sikap menghargai pendapat orang lain; (4) leading and inspiring, memiliki kemampuan memberikan contoh yang baik bagi orang lain.

Kedua, Strategi proses, dilakukan dengan mengembangkan kurikulum melalui penguatan bahasa (languages) dan pengembangan diri yang berwawasan global (enrichment and extension). Program bahasa di LPI Thursina IIBS Malang ini bertujuan untuk membangun kompetensi diri secara komunikatif sebagai alat dalam berinteraksi secara global. Program pengembangan dan perluasan kurikulum bertujuan untuk menanamkan kepercayaan diri dan berpengetahuan luas, LPI Thursina IIBS Malang memiliki berbagai program di luar kelas baik pengembangan diri dan keterampilan yang juga dapat bersifat refreshing.

Untuk program pengembangan diri, siswa dapat bergabung dengan berbagai program seperti LPI Thursina IIBS Malang. Program Students Association, pengusaha, memasak cerdas, pemimpin Pramuka, bulan sabit merah, ilmuwan, dan jurnalis. Untuk menumbuhkan nilai estetika siswa, SMA Thursina IIBS Malang juga menyediakan Islamic Calligraphy, House Keeping, Photography dan The Designer. Adapun untuk membangun wawasan global dan persahabatan, peserta didik bisa bergabung dalam program kunjungan belajar di luar negeri (Observasi, 21 Februari 2021).

Dalam rangka membangun dimensi kesadaran diri, lingkungan dan social LPI Thursina IIBS Malang menyelenggarakan berbagai program layanan sosial dan program olahraga dengan antara lain: berkuda, memanah, program kesehatan, dan program keolahragaan lainnya. Kemudian program pendidikan al-Qur'an secara gratis dan pemberian beasiswa ketiga, strategi output: komitmen pada kualitas lulusan yang holistik, berimbang, relevan dan modern menjadi generasi muslim-musimah abad modern yang berkepribadian Islami, berwawasan global dan berjiwa pemimpin.

Implementasi strategi pengembangan kurikulum pendidikan Islam model International Islamic Boarding School (IIBS) di Thursina IIBS Malang

Implementasi strategi pengembangan kurikulum dilakukan dengan membangun manajemen pengelolaan modern yang efektif dan akuntabel, perencanaan (planning) kurikulum menjadi bagian yang sangat penting di LPI Thursina IIBS Malang, sebagaimana Manajemen strategik (strategic 
management) yang didefinisikan beragam oleh para ilmuan sesuai dengan spesifikasi dan orientasi penerapan keilmuan dibidang manajemenn. Manajemen strategic sebagai satu paket keputusan dan tindakan yang menghasilkan formulasi dan implementasi rencana yang dirancang untuk meraih tujuan suatu perusahaan (Pearce Dan Robinson, 2008).

Proses perencanaan strategis dimulai dari penyusunan konsep model pengembangan kurikulum pendidikan Islam yang detail dan terukur sampai pada tahapan implementasi yang jelas dan proses evaluasi hasil yang berkelanjutan. Perencanaan kurikulum akan memberikan arah dan tujuan yang jelas beserta strategi pencapaian yang efektif. Prinsip manajemen modern adalah kesalahan dalam membuat perencanaan adalah sebuah kegagalan dan kerugian. Sebagaimana dikatakan dalam al-Qur'an adalah: Hai orang-orang yang beriman, bertakwalah kepada Allah dan hendaklah setiap diri memperhatikan apa yang telah diperbuatnya untuk hari esok (akbirat); dan bertakwalab kepada Allah, sesunggubnya Allah Maha mengetabui apa yang kamu kerjakan. (QS: Al-Hasyr:18)

Al-Qur'an diatas memberikan perintah agar senantiasa memperhatikan apa yang akan diperbuat, serta bersungguhsungguh dan mengevaluasi dampaknya dikemudian hari termasuk di akherat kelak. Beberapa cara yang dapat dilakukan mendesai system perencanaan yang efektif dan efisien secara berkelanjutan dari aspek waktu time management maupun strategi pencapaiannya strategy management. Proses pembelajaran di LPI Thursina IIBS Malang dilakukan melalui proses perencanaan yang matang sebelum mengimplementasikan kurikulum, yaitu dengan melakukan pengajaran di kelas sehingga mampu mencapai tujuan kurikulum dan pembelajaran dengan lebih efektif.

$$
\text { Jadi, strategi implementasi }
$$
pengembangan kurikulum dilakukan melalui proses organizational culture and refocusing the organization structure dan specialization class Moslem scholer, entrepreneur, sciencepreneur, CEO, professional). Berikut ini pengembangan kurikulum yang terintegrasi dan menjadi karakteristik dari model kurikulum yang diimplementasikan di LPI Thursina IIBS Malang, antara lain adalah:

\section{Misi Kurikulum Moslem Scholar}

Misi dari penjurusan Moslem Scholar Mencetak kader ulama' yang memiliki kualitas keilmuwan yang luas dan mendalam, integritas moral yang tinggi dan mampu menginspirasi sehingga bisa menjadi madu peradaban di tengah-tengah masyarakat. Kurikulum Moslem Scholar : (a) Studi Perkembangan Hukum Islam: Mata pelajaran ini menjelaskan tentang sejarah terbentuknya hokum Islam (tasyri') dan perkembangannya pada sejak diutusnya Rasulullah SAW sampai masa khulafa ar-rasyidin; (b) Prophetic Leadership dan Manajemen Dakwah: Mata pelajaran ini menjelaskan tentang landasanlandasan dakwah dalam al-quran dan hadits, 
musthalahat dalam dakwah, dan metode dakwah; (c) Sejarah Perkembangan Madhzab, Mata pelajaran ini menjelaskan tentang sejarah lahirnya madzhab fiqih (hukum Islam) terutama empat madzhab dalam sejarah Islam berserta landasan-landasan yang digunakan oleh masing-masing madzhab; (d) Strategi dan Komunikasi Dakwah Kontemporer: Mata pelajaran ini menjelaskan tentang tantangan dan strategi dakwah dari masa kenabian hingga era modern; (e) Pembaharuan Hukum Islam: Mata pelajaran ini menjelaskan tentang pembaharuan metodologi dalam penetapan hukum Islam dengan terbentuknya lembaga-lembaga fatwa; (f) Qawaid Fiqhiyyah: Mata pelajaran ini menjelaskan tentang kaidah-kaidah fiqih yang dipakai para ulama dalam menetapkan suatu hukum seperti kaidah al-umuru bimaqashidiba (Suatu perkara dilihat dari maksudnya); (g) Hadits: Mata pelajaran ini menjelaskan tentang hadits-hadits tematik, baik yang berhubungan dengan aqidah, hokum islam (syariah) dan akhlak; (h) Fiqih Kontemporer: Mata pelajaran ini menjelaskan tentang masalah-masalah kontemporer dalam hokum Islam seperti masalah bayi tabung, jual beli online, game online, bank asi, dll; (i) Sejarah Islam Nusantara: Mata pelajaran ini menjelaskan tentang sejarah masuknya Islam ke Indonesia dan perkembangannya; (j) Arabia: Mata pelajaran ini dikhususkan untuk mempersiapkan siswa dalam mengikuti ujian Arabia untuk Bahasa Arab; (k) Intagrated Qur'an and Islamic Studies Project. Mata pelajaran ini menjelaskan tentang projek/tugas karya tulis ilmiah tentang al-quran dan studi Islam; (l) Studi Organisasi Dakwah: Mata pelajaran ini menjelaskan tentang organisasi-organisasi dakwah yang ada di Indonesia dan metode serta strategi yang digunakannya (Thursina IIBS, 2021).

\section{Kurikulum Entrepreneurship}

Mencetak entrepreneur Muslim yang memiliki value \& belief entrepeneurship (nilai, perilaku, dan cara berpikir entrepreneur) dengan kompetensi advantage (kemampuan memilih solusi terbaik), creativity (kemampuan mengeluarkan ide), Ego (keinginan untuk membuat perubahan), Team (kemampuan untuk bekerja dengan orang lain). Kurikulum entrepreneurship antara lain: (a) Entrepreneurial Mindset. transformasi cara berpikir mindset adalah cara pandang terhadap kemandirian hidup. Mata pelajaran ini menanamkan betapa pentingnya Mindset Entrepreneur kepada siswa.

Peserta didik akan diajarkan bagaimana membangun karakter diri seorang entrepreneur yang mampu berpikir kreatif, mampu memecahkan masalah dan berpikir inovatif. Program Entrepreneurship sebagai tepat bagi kemajuan masyarakat dilingkungan lembaga pendidikan; (b) Technology And Innovation 1: Mata pelajaran ini memberikan spektrum luas bagi peserta didik mengenai peran teknologi dan inovasi dalam berbagai bidang kehidupan serta isu penting berkaitan dengan pengembangan inovasi. Mata 
pelajaran ini juga membahas perkembangan teknologi dan trennya di masa depan (Observasi, 21 Februari 2021).

Tren teknologi dan inovasi di berbagai sektor (ICT, bioteknologi, renewable energy, nanoteknologi dan lainnya) diberikan untuk melengkapi siswa menjadi seorang entrepreneur berbasis teknologi. Melalui proyek kelompok, peserta didik dilatih untuk dapat mengidentifikasi serta menganalisa secara sistematis dan kritis inovasi teknologi di dalam suatu produk; (c) Technology And Innovation 2: Mata pelajaran Teknologi dan Inovasi 2 ini memberikan gambaran kepada peserta didik tentang proses-proses ideal dalam pengembangan sebuah produk baru, mulai dari tahap idea generation sampai pada tahap launching sebuah produk; (d) Creativity And Innovation: Mata pelajaran ini akan mengeksplorasi perspektif kreativitas dan inovasi yang luas dan diterapkan pada individu, organisasi, bisnis serta masyarakat. Peserta didik akan belajar teknik dan metode untuk meningkatkan kemampuan berpikir kreatif dan inovatif mereka.

Tujuan mata pelajaran ini adalah untuk merangsang rancangan rencana kreatif dan inovatif setiap siswa dengan mensintesis pelajaran mereka dari literatur, pembelajaran dikelas dan tugas kelompok; (e) social Entrepreneurship and Innovation: Kewirausahaan sosial berfokus pada pengentasan masalah sosial dengan pendekatan entrepreneurial. Bidang ini berkembang secara pesat dan menarik perhatian banyak orang. Modul ini dirancang untuk menginspirasi para Peserta didik dan meningkatkan kesadaran akan peran dan pentingnya kewirausahaan sosial, khususnya di Indonesia.

Dalam mata pelajaran ini, peserta didik akan merancang, membuat dan mengembangkan projek bisnis berbasis sosial sebagai respon atas permasalahan social yang ada di sekitar; (f) Moslempreneur: Mata pelajaran ini menanamkan betapa pentingnya nilai-nilai keislaman menjadi ruh dalam menjalankan sebuah bisnis, siswa akan dikenalkan bagaimana figur Rosululloh dan kisah sahabat-sahabat lainnya sebagai seorang entrepreneur. Siswa akan diajarkan tentang studi kasus fiqih muamalat yang berhubungan langsung dengan entrepreneurship (g) Creating New Venture: Mata pelajaran ini dirancang untuk mengajarkan pada peserta didik proses menciptakan "venture" baru mulai dari idea hingga launch. Istilah venture disini bukan hanya berfokus pada bagaimana menciptakan sebuah usaha baru, namun juga bagaimana membimbing peserta didik untuk mencapai cita-cita dalam karirnya dengan dimulai pada entrepreneurial venture.

Konsep mata pelajaran ini lebih menekankan pada pendekatan mentoring secara individu kepada peserta didik, dengan mengarahkan dalam menggapai karir yang dicita-citakan sesuai dengan passion dan kompetensi yang dimiliki. Mata pelajaran ini tidak hanya mengajarkan pengetahuan tentang Entrepreneur, tapi membimbing 
peserta didik untuk menjadi seorang entrerepreneur; (h) Integrated Entrepreneurial Project. Mata pelajaran ini berfokus pada proses penciptaan usaha baru (new venture creation) berbasis teknologi. Peserta didik akan mengaplikasikan teknik dan metode penciptaan peluang hingga bagaimana mengembangkan ide menjadi sebuah usaha yang memiliki dampak dan berkelanjutan.

Peserta didik akan merancang, membuat dan mengembangkan real project bisnis berbasis teknologi sebagai respon permasalahan fundamental dunia. Mata pelajaran ini dirancang agar peserta didik bukan hanya bisa mengaplikasikan ilmu yang diperolehnya saja, tetapi juga diasah sebagai seorang problem solver, decision maker, kreatif dan innovatif dengan pola pikir keilmuan yang holistic, (i) Integrated Entrepreneurial Project (2) Mata pelajaran ini merupakan lanjutan dari mata pelajaran Integrated Entreprenurial Project. Pada proses pembelajaran kali ini akan berfokus pada bagaimana pengembangan dan eksekusi dari ide bisnis yang telah dikembangkan. Mata pelajaran ini dirancang agar peserta didik bukan hanya bisa mengaplikasikan ilmu yang diperolehnya saja, tetapi juga diasah sebagai seorang problem solver, decision maker, kreatif dan innovatif dengan pola pikir keilmuan yang holistik.

\section{Kurikulum Sciencepreneur}

Misi Sciencepreneur adalah mewujudkan ilmuwan muslim berwawasan global yang memiliki kompetensi collaboratif, berpikir kritis critical Thinking, Logis logical thinking dan ilmiah scientific dalam menyelesaikan masalah.

Kurikulum Sciencepreneur antara lain adalah: (a) Sciencepreneur Mindset: Mata pelajaran ini diajarkan untuk membangun karakter siswa seperti peduli, kritis dan peka terhadap masalah disekitar (intrapreneur). Kemampuan siswa akan diasah baik mindset, skillset, dan toolset sebagai seorang sciencepreneur. Siswa akan ditanamkan bahwa seorang ilmuwan tidak hanya menciptakan penemuan saja tapi juga mampu berbagi manfaat kepada orang lain; (b) Systems Thinking: Mata pelajaran ini akan mengeksplorasi bagaimana siswa belajar teknik dan metode untuk meningkatkan kemampuan berpikir sistemik. Dengan Systems Thinking siswa akan melihat sistem melalui perspektif yang lebih luas (Holistic). Sehingga pola pikir siswa lebih akurat dan realistis dalam menganalisa suatu masalah; (c) English for Science: Mata pelajaran ini akan mengembangkan kemampuan siswa dalam memahami dan menggunakan istilah atau kosakata yang spesifik digunakan pada cabang sains. Siswa akan mempelajari dan memahami kosa kata, struktur dan penggunaan bahasa inggris yang dapat ditemukan dalam buku teks akademis, artikel dan pembelajaran sains; (d) Science and Technology: Mata pelajaran ini disusun untuk memberikan wawasan sejarah dan penemuan terbaru baik dibidang sains maupun teknologi 
mulai dari yang sederhana hingga termutakhir.

Siswa juga akan diminta untuk mengupas tuntas dan mempresentasikan penemuan di bidang sains dan teknologi yang telah ada. Hal ini merupakan sarana motivasi dan pengembangan "scientific thinking" bagi siswa; (e) Science Literacy: Mata pelajaran ini akan membangun kesadaran dan mengembangkan kemampuan siswa untuk kritis terhadap kebenaran suatu berita, menganalisis data dan mereview artikel ilmiah. Pelajaran ini juga akan mengajarkan bagaimana mengkomunikasikannya dalam bentuk karya tulis, poster dan presentasi oral secara ilmiah dan menarik; (f) Creativity and Innovation: Mata pelajaran ini akan mengeksplorasi perspektif kreativitas dan inovasi yang luas dan diterapkan pada individu, organisasi, bisnis serta masyarakat. Siswa akan belajar teknik dan metode untuk meningkatkan kemampuan berpikir kreatif dan inovatif; (g) Sustainable Futures: Mata pelajaran ini di susun dengan pemaparan konsep ekologi dan permasalahan lingkungan dari sudut pandang ilmu pengetahuan terkait.

Tujuan utama dari penyampaian mata pelajaran ini adalah untuk membangun kepekaan siswa terhadap permasalahan lingkungan serta hubungan antara manusia dan lingkungannya. Mata pelajaran ini fokus pada konsep isu permasalahan yang nyata (real-life issues). Siswa akan diajarkan untuk mencari akar permasalahan lingkungan di sekitarnya hingga membahas isu dunia dan merumuskan solusi yang tepat; (h) Creating New Venture: Mata pelajaran ini dirancang untuk mengajarkan pada siswa proses menciptakan venture baru mulai dari idea hingga launch. Proses venture difokuskan pada bagaimana membimbing siswa untuk mencapai cita-cita dalam karirnya dengan dimulai pada entrepreneurial venture; (i) Qur'an \& Science: Mata pelajaran ini dirancang untuk menkaji fakta-fakta ilmiah yang tersurat dalam al-qur'an. Mengintegrasikan pengetahuan sains dengan al-Qur'an dari berbagai sumber; (j) Integrated Sciencepreneur Project I: Mata pelajaran ini fokus pada proses penciptaan product inovasi bidang sains. Siswa akan mengaplikasikan teknik dan metode penciptaan peluang hingga bagaimana mengembangkan ide menjadi sebuah produk yang memiliki manfaat bagi masyarakat; (k) Integrated Sciencepreneur Project II: Mata pelajaran ini merupakan lanjutan dari mata pelajaran Integrated Sciencepreneur Project I. Pada proses pembelajaran kali ini akan berfokus pada pengembangan dan eksekusi dari ide produk yang telah direncanakan (Dokumentasi, 2021).

\section{Kurikulum Profesional}

Misi Profesional adalah mewujudkan profesional muslim yang menjunjung tinggi etika dan budaya kerja, memiliki motivasi internal yang tinggi, kemampuan kolaborasi dan adoptif terhadap teknologi terbaru sehingga mampu menginspirasi kurikulum profesional, antara lain adalah: 
Intrapreneurial Mindset: Mata pelajaran ini akan mengajarkan bagaimana membangun karakter diri seorang intrapreneur yang mampu memecahkan masalah dengan kreatif dan inovatif. Kemampuan siswa akan diasah baik mindset, skillset, dan toolset sebagai seorang intrapreneur; (b) Systems Tbinking: Mata pelajaran ini akan mengeksplorasi bagaimana siswa belajar teknik dan metode untuk meningkatkan kemampuan berpikir sistemik. Dengan Systems Thinking siswa akan melihat sistem melalui perspektif yang lebih luas (Holistic). Sehingga pola pikir siswa lebih akurat dan realistis dalam menganalisa suatu masalah. Siswa akan diberikan studi kasus dengan belajar dari profesional dibidang tertentu untuk melatih kemampuan berpikir sistemik sesuai profesi; (c) Moslem Professional And Business Ethics: Mata pelajaran ini akan mendalami bagaimana etika menjadi seorang profesional muslim, etos kerja seorang muslim.

Dengan menjaga etika dan profesionalisme akan menumbuhkan kepercayaan sehingga mempermudah seseorang untuk berkomunikasi dan bersikap dalam menjalanakan sebuah profesi. Siswa akan diberikan studi kasus dengan belajar dari profesional dibidang tertentu untuk mengenali kode etik kode etik berbagai profesi; (d) Teamwork and Collaboration : Matapelajaran ini akan mengeksplorasi bagaimana siswa dalam membangun sebuah tim, tahapan-tahapan dalam membangun tim dan bekerjasama dalam tim; Personal
Marketing: Matapelajaran ini akan membimbing siswa untuk memperkenalkan, mempengaruhi dan meyakinkan kelompok masyarakat bahwa dirinya memiliki kompetensi dan kemampuan yang dibutuhkan melalui berbagai media; (f) Technology And Innovation: Mata pelajaran ini memberikan spektrum luas bagi siswa mengenai peran teknologi dan inovasi dalam berbagai bidang kehidupan serta isu penting berkaitan dengan pengembangan inovasi. Mata pelajaran ini juga membahas perkembangan teknologi dan trennya di masa depan.

Tren teknologi dan inovasi di berbagai sektor (ICT, bioteknologi, renewable energy, nanoteknologi dan lainnya) diberikan untuk melengkapi siswa menjadi seorang intrapreneur berbasis teknologi. Siswa akan diberikan studi kasus dengan belajar dari profesional untuk memperkenalkan teknologi terbaru yang digunakan pada profesi tertentu; (g) Communication Skill: Mata pelajaran ini melatih skill berkomunikasi. Skill ini merupakan sarana yang digunakan dengan bahasa lisan meliputi proses penyampaian gagasan dan ide dengan tujuan untuk memberikan informasi atau meyakinkan orang lain; (h) Financial and Invesment Literacy: Pada matapelajaran ini siswa akan mempelajari bagaimana cara mengatur keuangan yaitu dalam merencanakan, mendapatkan, mengelola dan melaporkan sumber keuangan secara akuntabel dan efektif; (i) Professional Road Map: Mata 
pelajaran ini dirancang untuk mengeksplorasi siswa untuk mengenali potensi diri, menentukan profesi yang sesuai dengan potensi dan minat.

Langkah-langkah dalam mewujudkan profesi yang telah dipilih; (j) Internship \& Professional Project: Mata pelajaran ini berfokus pada proses penciptaan produk inovasi sesuai bidang. Siswa akan mengaplikasikan teknik dan metode penciptaan ide hingga bagaimana mengembangkan ide menjadi sebuah produk inovasi yang memiliki dampak untuk masyarakat; (k) Internship \& Professional Project II: Mata pelajaran ini merupakan lanjutan dari mata pelajaran Integrated Profesional Project. Pada proses pembelajaran kali ini akan berfokus pada bagaimana pengembangan dan eksekusi dari ide produk yang telah dikembangkan.

Selain proses dan tujuan yang berimbang, implementasi kurikulum di LPI Thursina IIBS Malang juga berupaya menjaga isi/konten kurikulum dan metode pengajaran selalu up to date dan sesuai dengan tuntutan perubahan zaman. Kurikulum yang kurang relevan akan merugikan santri tidak hanya dalam menghadapi tes dan ujian di sekolah akan tetapi secara signifikan merugikan dalam menghadapi berbagai persoalan hidup yang semakin komplek dan menantang. Oleh karena itu, kajian terhadap muatan kurikulum menjadi sangat strategis dan secara terusmenerus perlu dilakukan baik konten materi kurikulum al-Quran, diniyah, nasional, bahasa, pengembangan diri santri dan kurikulum internasional.

Model kurikulum di LPI Thursina IIBS Malang dituntut untuk up to date sesuai dengan perkembangan zaman. Kurikulum yang relevan dengan kondisi lingkungan sekitar peserta didik, perkembangan psikologis peserta didik, karakter belajar akan memudahkan peserta didik dalam meraih prestasi dalam belajar. Oleh karena itu, semua pendidik dan stakeholder di LPI Thursina IIBS Malang dapat memberikan pembelajaran yang kreatif dan menyenangkan, dengan mengintegrasikan berbagai strategi pembelajaran baik modern maupun salaf sebagaimana Rasulullah telah contohkan dalam hadits. Disamping itu, pendidik dituntut mengembangkan dan meningkatkan kemampuan pembelajaran melalui berbagai program pengembangan kompetensi yang berkelanjutan (Wawancara, Wahyu, Principle Islamic Foundation Curriculum Thursina IIBS Malang, 2021).

Menurut Sukmadinata, ada beberapa model pengembangan kurikulum yang penting untuk perhatikan, antara lain adalah: the administrative (line staff) model, the grass roots model, Beauchamp's system, the demonstrartion model, Taba's inverted model, Roger's interpersonal relations model dan the systematic action research model. Model pengembangan kurikulum ditegaskan oleh Nana Sayodah, yang menyatakan bahwa model pengembangan kurikulum perlu melibatkan berbagai stakeholder seperti komite, guru, pemerhati 
Pendidikan, dan peserta didik. Kurikulum dikembangkan dalam rangka memenuhi kebutuhan pemangku kebijakan dan pihakpihak yang berkepenyingan (stakeholder) dalam memajukan Pendidikan Islam yang meliputi orang tua siswa, masyarakat, dan komponen pendidikan lainnya. Penyusunan kurikulum dilakukan dengan mengikuti prosedur dalam dunia penelitian melalui metode action research (Nana Syaodih, 2005)

Selain aspek dukungan dan penguatan organizational culture management and refocusing the organization, pengembangan kurikulum pendidikan Islam model International Islamic Boarding School pengembangan kurikulum diimplementasikan melalui aspek-aspek spesialisasi atau peminatan specialization class (Moslem scholer, entrepreneur, sciencepreneur, CEO, professional), asumsi peminatan ini didasarkan pada tingkat perkembangan atau jenjang pendidikan di LPI Thursina IIBS Malang

Evaluasi strategi pengembangan kurikulum pendidikan Islam model International Islamic Boarding School (IIBS) di Thursina IIBS Malang

Evaluasi strategi pengembangan kurikulum pendidikan Islam model International Islamic Boarding School, evaluasi menyesuaikan dengan standart kurikulum perpaduan antara kurikulum pesantren, nasional, dan internasional, evaluasi dilakukan secara menyeluruh (bolistic) mulai dari input, proses, output, dan outcome dengan melibatkan seluruh stakeholder dari jajaran direksi, manajemen, guru, staf serta wali santri dan alumni sebagai bahan masukan dalam pengembangan kurikulum.

Proses evaluasi implementasi strategik pengembangan kurikulum secara holistik menghilangkan definisi kurikulum yang sebelumnya menjadi otoritas pendidik dan struktur lembaga (eksklusif) menjadi dasar penguat bahwa evaluasi yang holistik dan seimbang akan menghasilkan tujuan pengembangan kurikulum sesuai dengan tujuan bersama multidimensional tidak terbatas pada lembaga internal pendidikan makna ini sebagaimana dalam studi yang dilakukan oleh Scubert, bahwa keragaman pengembangan kurikulum dirangkum dalam delapan image kurikulum, dalam literaturnya disebutkan teori the images of curriculum, yaitu:

Kurikulum bermakna image mata pelajaran content or subject matter; kurikulum yang memiliki makna program atau aktivitas terencana program or planned activities; kurikulum yang bermakna hasil belajar atau apa yang diharapkan intended learning outcomes; kurikulum bermakna reproduksi budaya cultural reproduction; kurikulum yang bermakna pengalaman (experience); kurikulum yang bermakna konsep-konsep tertentu discrete task and concept; kurikulum yang memiliki makna program atau agenda rekonstruksi sosial agenda for social reconstruction; dan kurikulum yang bermakna track yang telah dilalui atau dilaksanakan (W. H. Schubert, 1986). 


\section{Pembahasan}

Manajemen strategik penting untuk didesain secara berkelanjutan dalam rangka pengembangan kurikulum model International Islamic Boarding School secara komprehensif di LPI Thursina IIBS Malang. Manajemen strategik pengembangan model kurikulum tersebut dilakukan melalui beberapa tahapan antara lain: Pertama, Strategi input: tahapan strategi ini memadukan kurikulum kepesantrenan terintegrasi secara nasional dan diakhir jenjang pendidikan, peserta didik akan lulus dalam ujian UN Pendidikan nasional yang diselenggarakan oleh Negara. Kurikulum internasional kemudian mengintegrasikan antara kurikulum nasional dan kurikulum internasional, yaitu Kurikulum mengacu pada Coumbrige, peserta didik yang dinyatakan lulus dari LPI Thursina IIBS Malang akan memiliki piagam Coumbrige (Wawancara, Wahyu Eko, Islamic Foundation Curriculum Thursina IIBS Malang, 2021)

Sebagaimana definisi tentang manajemen strategik adalah suatu seni dan ilmu dari proses pembuatan atau desain (formulating), penerapan (implementing), dan evaluasi (evaluating) keputusan-keputusan strategis antar fungsi-fungsi yang memungkinkan lembaga organisasi mencapai tujuan-tujuan dimasa yang akan datang (Agustinus Sri Wahyudi, 2006).

Manajemen strategik dapat diimplementasikan dalam konteks pengembangan kurikulum secara lebih luas, konsep tersebut dikarenakan manajemen strategic adalah sebuah seni dan ilmu untuk memformulasi, mengimplementasi, dan mengevaluasi keputusan lintas fungsi yang memungkinkan organisasi dapat mencapai tujuannya, sebagai serangkaian keputusan dan tindakan manajerial yang menentukan kinerja organisasi secara jangka panjang (Pearce Dan Robinson, 2008)

Implementasi model pengembangan kurikulum Pendidikan Islam yang beragam di dalam Lembaga Pendidikan Islam, harus melalui proses implementasi kurikulum secara seimbang antara dimensi psikologis dengan dimensi fisik. peserta didik. Peserta didik perlu dibekali dengan budaya keagamaan melalui praktik beribadah dan berdiskusi dengan peserta didik sejawat. Dimensi keseimbangan spiritual menjadi karakter dalam pengembangan kurikulum LPI Thursina IIBS Malang. Kurikulum yang berimbang akan mengantarkan peserta didik menjadi pribadi yang unggul dan dapat meraih prestasi dan kesuksesan serta kebahagiaan dunia dan akherat.

Implementasi strategi tersebut diatas sebagaimana ditegaskan dalam kajian pemikiran Pendidikan Islam tentang pengembangan kurikulum Pendidikan Islam, model pengembangan kurikulum pendidikan didasarkan pada capaian yang maksimal serta kesesuaian dengan kurikulum nasional serta kurikulum lain yang menjadi landasan dalam pengembangan kurikulum di lembaga Pendidikan. Dari hal tersebut pengembangan 
model kurikulum dalam sistem pendidikan bersifat sentralistik tidak bersifat desentralistik. Disisi lain, kurikulum yang cenderung subyektif berbeda dengan kurikulum yang bersifat humanis, teknokratik, konstruksi social atau teknologik (Wiyono, 2017)

Beberapa landasan yang penting untuk diperhatikan dalam konsep dan konteks implementasi strategi pengembangan kurikulum ketika hendak mengembangkan atau merencanakan suatu kurikulum lembaga pendidikan Islam di Indonesia, antara lain adalah:

Landasan spiritual keagamaan, model pengembangan kurikulum dalam lembaga pendidikan Islam khususnya pondok pesantren yang menerapkan kelembagaan modern dimasa depan perlu memperhatikan aspek dan landasan ketuhanan atau dimensi spiritual terutama konsep keberagamaan yang berpijak pada ideologi nation state yakni Pancasila sila kesatu Ketuhanan Yang Maha Esa. Landasan pijak dasar kehidupan bernegara di Indonesia menyatakan bahwa kepercayaan dan ketakwaan terhadap Tuhan Yang Maha Esa sesuai dengan agama dan kepercayaannya masing-masing individu (Oemar Hamalik, 2001).

Landasan berikutnya yang penting sebagai acuan dalam mengembangkan model kurikulum Pendidikan Islam adalah Landasan filsafat. Perkembangan kurikulum dalam dunia pendidikan lebih banyak dipengaruhi oleh dua hal yang mendasar, yaitu cita-cita masyarakat dan kebutuhan peserta didik yang hidup di masyarakat. Landasan filsafat adalah landasan yang didasari atas cinta pada kebijaksanaan (love of wisdom). Agar seseorang dapat berbuat dan berpikir bijak, maka harus berpengetahuan, pengetahuan tersebut diperoleh melalui proses berpikir secara sistematis, logis dan radikal. Situasi berpikir seperti ini sesuai dengan penerapan pengembangan kurikulum Pendidikan Islam agar tidak hanya terpola pada dimensis teks atau doktrin keagamaan akan tetapi mampu menkontekstualisasi dalam dimensi teknokratik bernegara. Yang terakhir adalah Landasan Sosio-budaya. Nilai-nilai sosialbudaya terutama nilai masyarakat bersumber dari hasil karya akal budi manusia, sehingga dalam menerima, menyebarluaskan, mengembangkan dan melestarikannya manusia menggunakan akal dan pikiran (Oemar Hamalik, 2001)

Dari beberapa konsep manajemen strategik dan landasan berpijak dalam pengembangan kurikulum pendidikan Islam diatas, maka Pendidikan Islam akan menemukan momentum keunggulan dalam mengembangkan kelembagaan khususnya Lembaga Pendidikan Islam, sehingga persepsi masyarakat tentang perkembangan Lembaga Pendidikan Islam yang dianggap tradisional dan tidak mampu berdialektika dengan perubahan zaman akan beralih menjadi rujukan dalam memajukan system Pendidikan di Indonesia ditengan arus 
modernisasi terutama diera revolusi industry 4.0 saat ini.

\section{KESIMPULAN}

Formulasi strategi pengembangan kurikulum pendidikan Islam model International Islamic Boarding School dimulai dari tahapan: pertama, Strategi input: memadukan kurikulum kepesantrenan, nasional, dan internasional, dengan harapan peserta didik diakhir jenjang pendidikan lulus secara formal dalam ujian UN yang diadakan Negara, dan kurikulum internasional dengan mengintegrasikan antara kurikulum nasional dan internasional, yaitu pengembangan Kurikulum model Coumbrige, lulusan dari LPI Thursina IIBS Malang akan memiliki piagam Coumbrige, Kedua, Strategi proses: mengembangkan kurikulum melalui penguatan bahasa (languages) dan pengembangan diri yang berwawasan global (enrichment and extension), ketiga, strategi output: komitmen kualitas lulusan yang berkepribadian Islami (morally eccelent), berwawasan global (internationally minded), dan berjiwa pemimpin (an inspiring leader).

Implementasi strategi pengembangan kurikulum pendidikan Islam model International Islamic Boarding School (IIBS), mengimplementasikan strategi pengembangan kurikulum melalui proses organizational culture and refocusing the organization dan specialization class (Moslem scholer, entrepreneur, sciencepreneur, CEO, professional).

Evaluasi strategi pengembangan kurikulum pendidikan Islam model International Islamic Boarding School, evaluasi menyesuaikan dengan standart kurikulum perpaduan antara kurikulum pesantren, nasional, dan internasional, evaluasi dilakukan secara menyeluruh (bolistic) mulai dari proses perencanaan (input), implementasi, output, dan outcome yang melibatkan seluruh stakeholder dan alumni sebagai bahan masukan dalam pengembangan kurikulum.

\section{DAFTAR PUSTAKA}

Abuddin Nata. 2011. Pendidikan Karakter dalam Wacana Intelektual Muslim dan Khazanah Dunia Pendidikan Islam, Makalah Seminar, Institut Agama Islam (IAIN) Imam Bonjol, Padang Agustinus Sri Wahyudi, Manajemen Strategik: Pengantar Proses Berpikir Strategik, (Jakarta: Binarupa Aksara, 1996)

Fred R. David, Strategic Management, 13th editiion, (New Jersey: Prentice Hall, 2011)

John W. Creswell, Research Desaign: Pendekatan Kualitatif, Kuantitatif dan Mixed (Yogyakarta: Pustaka Pelajar, 2014)

John A. Pearce dan Richard B. Robinson Jr . Manajemen Strategis: Formulasi, Implementasi dan Pengendalian. Alih Bahasa: Yanivi Bachtiar dan Christine (Jakarta: Salemba Empat. 2008)

Masykuri Bakri, Metodologi Penelitian Kualitatif: Tinjauan Teoritis dan Praktis (Surabaya: Visipress Media, 2013) 
Miles, M.B. \& Huberman, A.M., Qualitative Data Analysis, (Beverly Hills, California: SAGE Publication

Muhammad Zaini, Pengembangan Kurikulum Konsep Implementasi Evaluasi dan Inovasi. (Yogyakarta: Teras, 2009)

Nana Syaodih Sukmadinata, Pengembangan Kurikulum teori dan Praktek, (Bandung: PT Remaja Rosda Karya, 2007)

Oemar Hamalik, Kurikulum dan Pembelajaran. (Jakarta: Bumi Aksara, 2001)

Ramayulis, Ilmu Pendidikan Islam, Jakarta: Kalam Mulia, 2008)

Suparlan, Tanya Jawab Pengembangan Kurikulum dan Materi Pembelajaran, (Jakarta: Bumi Aksara, 2011)

Syaiful Sagala, Konsep dan makna Pembelajaran. (Bandung: Alfabeta, 2010), Thomas L. Wheelen, \& J. David Hunger, Strategic management and business policy: toward global sustainability, 13th edition, (United States of America: Prentice Hall, 2012)

UU No. 20 tahun 2003, Sistem Pendidikan Nasional, (Jakarta: Depag, 2003)

Vincent Gaspersz, All-in-one Strategic Management. (Bogor: Vinchristo

Publication, 2012

W. H. Schubert, Curriculum: Perspective, Paradigm and Possibility, (New York: MacMillan, 1986)

Wiyono, D. (2017). Pemikiran Pendidikan Islam: Konseptualisasi Pendidikan Karakter Dalam Perspektif Intelektual Islam Klasik. Nidhomul
Haq : Jurnal Manajemen Pendidikan

Islam, 2(3), 164-179. https://doi.org/10.31538/ndh.v2i3. 180. 
